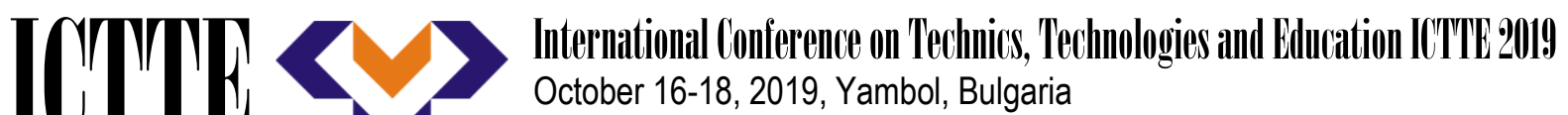 \\ www.ictte.eu
}

\section{THE SCREEN-WAY OF FORMING WEDDING GRAPHICS IN THE UKRAINIAN TRADITION}

\author{
Alla Slavinska, Tatyana Verzhbyczka, Oksana Syrotenko \\ Khmelnitskyi National University \\ Institytska str., 11, Khmelnitskyi, Ukraine, 29016 \\ Postal address of the institution, phone/ mobile: $+38(097) 93-45-291$, e-mail: \\ sirotenko@email.ua
}

\begin{abstract}
The "screen" way of determining the stylistics of the Ukrainian wedding dress on the basis of the rhythmic structure of an ethnic costume is offered. The modern ensembles of the bride and groom in the Ukrainian style are actually analyzed. The photos plates of ideas for wedding ensembles for the "screen"- survey are developed. The capsules of the traditional Ukrainian ethnic dress in the compositional transformation of the bride's wedding dress have been explored. A short notation of the geometry of a form of a wedding dress in the Ukrainian style has been developed. The triangle of the compositional dominant of the main part of the embroidery and the identity of the authenticity of the image is determined.
\end{abstract}

Keywords: Ukrainian traditions, rhythmic string, ensemble capsule, "screen"-survey, transformation, compositional dominant, style.

\section{INTRODUCTION}

The Ukrainian ethnic group is characterized by a deep historical memory in ritual traditions. The current state of our society is characterized by an increase in the ethnic consciousness of the population, an increase in its interest in national history and culture, and the awareness of the need to preserve the traditions of the people as a gene pool of its spirituality [24]. The inexhaustibility of the sources of traditional clothes, the appeal to the traditions of folk life and wedding ceremonies determine the relevance of the combination of ethnicity with modernity in the method of designing the wedding ensemble in general by determining the optimal version of the stylistics of the Ukrainian wedding dress on the basis of the structural recording of the links of elements of the art form and ethnic capsules.

In the semiotic aspect, the Ukrainian wedding is a code of national mentality. It was associated not only with the marriage of the young people, but also the combination of two families. It was a large-scale and responsible event in which many people took part in the role of elders, matchmakers, best men, bridesmaids, lights, friends, boyars, musicians, cooks, invited relatives and neighbors [26].

Everything, from clothes and accessories to folk shows, should contain elements of the Ukrainian national style. The bright clothes of guests in embroidered clothes, the beautiful design of the hall in folk style, Ukrainian national food and the bride, who is not in the usual dress, but in a luxurious dress with ethnic elements or with embroidery are essential elements of a wedding ceremony. The image of the bride and groom is a testimony to the spirituality of the wedding in the Ukrainian style.

An integral feature of the Ukrainian traditional wedding capsule is the complexity. The main components of the outfit complexes were the linen, waist elements of wear, breast elements 


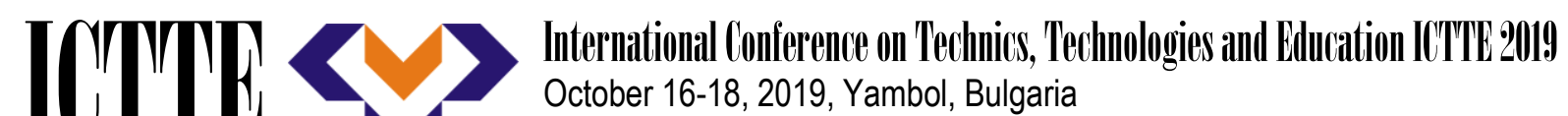 www.ictte.eu}

and outerwear. The wedding complex was an important social indicator, emphasizing the property and family status of a person, his age, nationality, and regional features.

\section{METHODS}

The expressiveness and functionality of the Ukrainian wedding costume were achieved through the use of various materials, the simplicity and workability of structures and shapes, the richness of types, techniques and compositions of accessories and decorations, the unity of constructive, technological and artistic techniques [18].

The character of the form is expressed by lines. As geometric analogues of silhouette forms of clothing, more complex geometric shapes can appear which are connected in their contour by straight lines and curved lines.

On the example of a wedding dress typical for the Podillya region of Ukraine [11] (Figure 1, a), a short recording of the rhythmic composition of the composition is made, which is executed by the vertical (Figure 1, b) and horizontal lines (Figure 1, c).

In both cases, the shape has a calm character: its silhouette is accented with straight soft lines. When combining vertices and horizontal lines (Figure 1, d), there is an impression of the ratio of parts and the whole, which gives the perception of harmony.

The character of the traditional form is clearly traced - it is an oval (Figure 1, e). The accents in the depicted costume emphasize the main parts of the shaping masses.

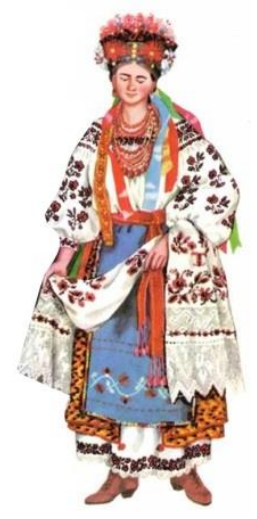

a

women's wedding

dresses of the

southern region

of Podillya
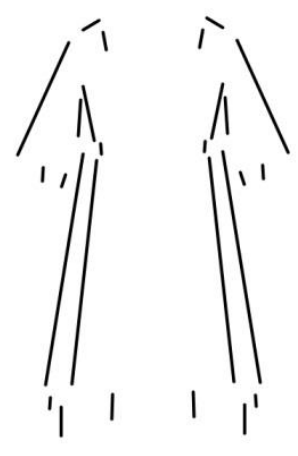

b

recording of the rhythmic structure in the vertical lines

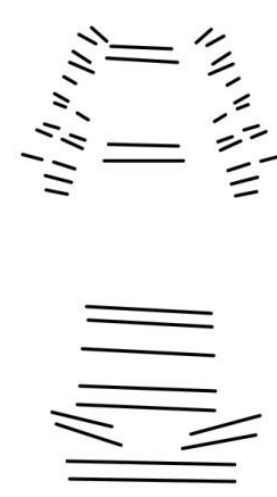

C

recording the rhythmic structure in the horizontal lines

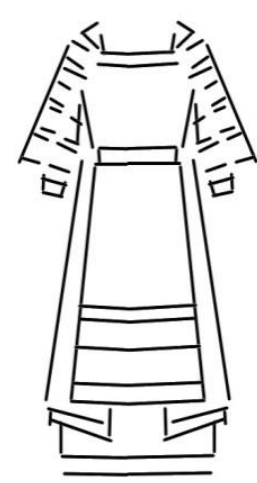

d

general recording of the rhythmic structure

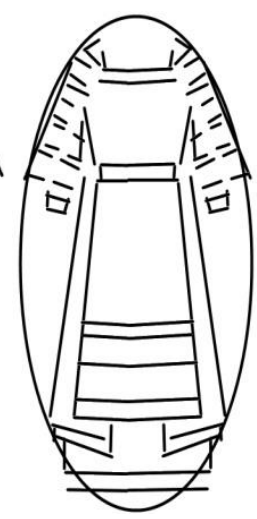

e

oval character of the form of a traditional outfit

Figure 1. Analysis of the rhythmic order of the ethnic wedding costume of Podillya

The sketch of a scheme of pure form of a folk costume without decor, where the lines of cut (lines of design) are the limits of proportional formations and rhythmic patterns, is the starting point for creating a modern form of a wedding dress. In this costume there is a gradual nuance change of the external form of one object to the full exhaustion of the adopted scheme, until the moment of a fundamental change in form [7]. 


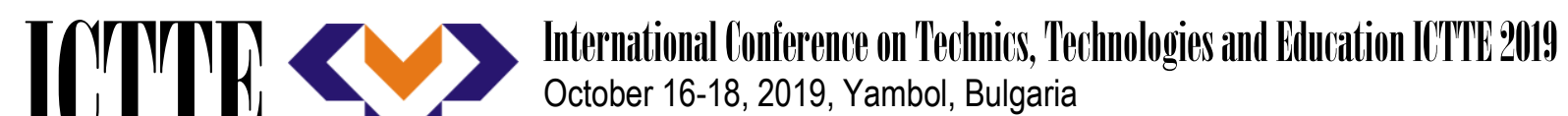 www.ictte.eu}

\section{EXPERIMENTAL}

A capsule is an optimal group which includes from five to eight items of clothing that are commonly used and interconnected with each other in style and color [13]. According to the results of the poll in the social network "Vkontakte", the traditional wedding gown capsule of the bridegroom's main outfit includes a suit, a shirt and a shoe. The traditional wedding capsule of the bride's main dress includes a dress, a headgear, a bouquet and shoes.

One of the main components of an ideal bridegroom's wedding image is a man's shirt. Its choice depends on the tie and costume model. Depending on the cut, the shirt may be classic, fit and free [9].

The classical shirt belongs to the office style of clothing. It is chosen most often, because it is suitable practically for all men, regardless of the figure and body build.

The fitted shirt features an adjacent trim and therefore suits men with a sporty and slim body. Free shirts combine convenience and rigor. With a free cut it is allowed that the shirt can be 1-2 sizes larger than the parameters of the figure of its owner.

The collar is a very important part of the shirt. The types of collars and their combination with the ensemble are presented in Figure 2.

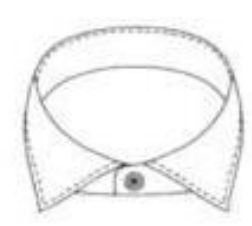

Shark

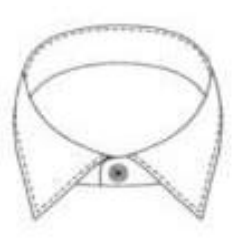

Kent

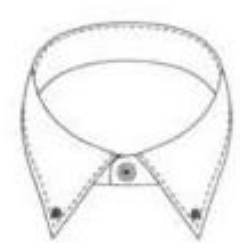

Button-Down

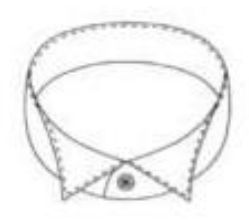

Mandarin

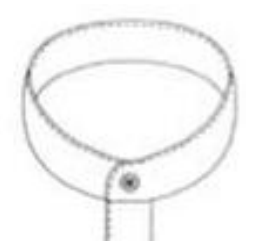

Butterfly

Figure 2. Types of cut-outs of men's shirts

Cuffs are an integral part of a man's shirt. They come in two types: cuff links (French cuffs) and buttons (regular cuffs). For the wedding ceremony in the Ukrainian style, the following ensembles of the bridegroom are the most common: a traditional embroidered shirt with trousers (Figure 3, a); a modern embroidered shirt with short sleeves, a Ukrainian belt and classic trousers (Figure 3, b), an embroidered shirt and a classic suit (jacket, trousers) (Figure 3, c); a vest and a tie in the color of the selected themes (Figure 3, g) and a suit (jacket, pants, vest, shirt, tie) (Figure 3, d). To determine the most popular ensemble, a "screen" was conducted, that is a survey of 132 respondents. The ensemble (Figure 3, b) which received the most votes consists of a modern embroidered short-sleeved shirt, Ukrainian belt and classic trousers $(37,1 \%)$.

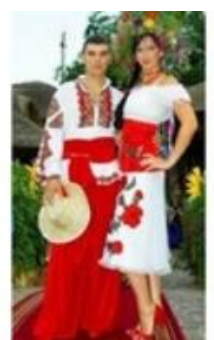

a

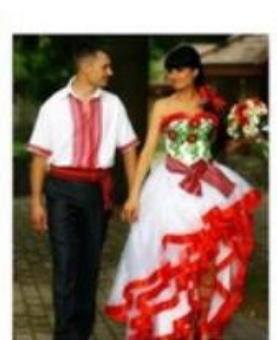

b

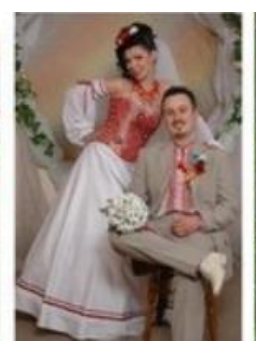

C

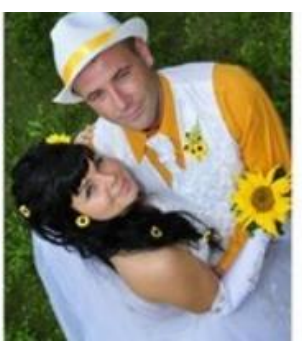

d

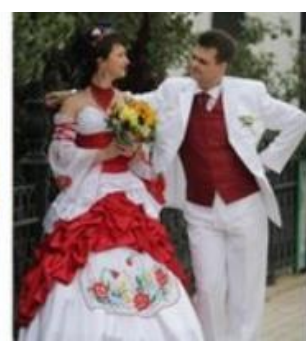

e

Figure 3. Topical ensembles of the bridegroom in the Ukrainian style

Proceedings of IITTI22018 ISSN 1314-9474 


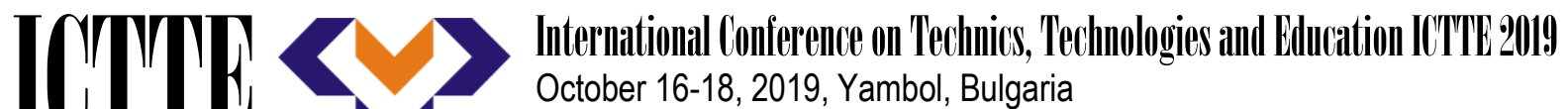 \\ www.ictte.eu}

To determine the type and location of the embroidery on the shirt [5], a screen was made "- a survey, in which 118 respondents participated. The 5th option (Figure 4, e) got the largest number of votes $(36,4 \%)$, so it is the most typical.

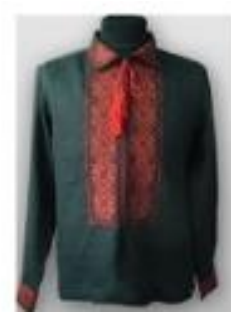

a

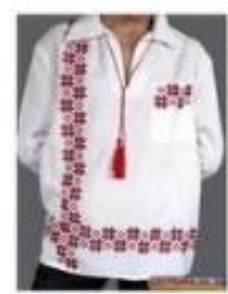

b

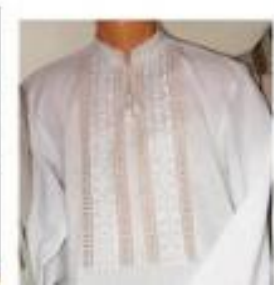

C

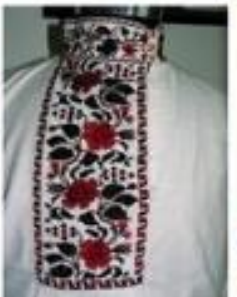

d

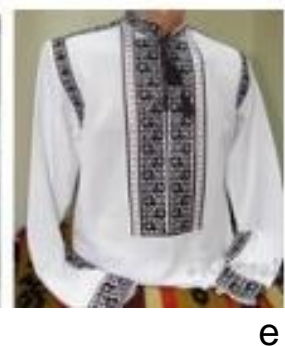

e

Figure 4. Current decorations of a man's shirt

Additions to the men's wedding ensemble include a tie, a headgear and a boutonniere. Tie is an important aspect of the bridegroom's wedding dressing. The following criteria must be taken into account when choosing a tie: pattern, color, length and width, type of fabric, as well as the quality of the fabric. Characteristics of neckties for decoration are presented in Figure 5.

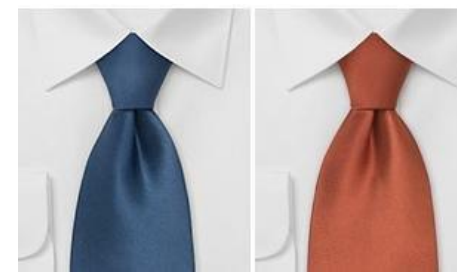

a) plain

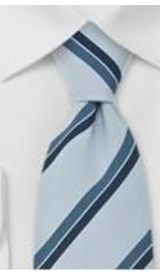

b) striped

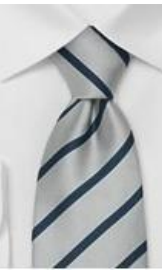

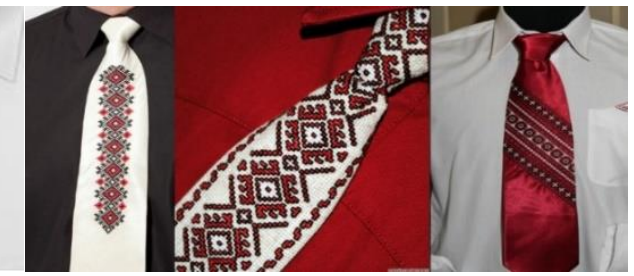

c) with embroidered folk motifs

Figure 5. Characteristics of neckties by decoration

The length of a tie usually varies within $130-150 \mathrm{~cm}$, and the width is $6-9 \mathrm{~cm}$. The length of a neck tie must cover the belt buckle. The width is selected according to the bridegroom's body and the width of the lapel jacket. The wider shoulders and lapels are, the wider should be the tie. There are also narrowed neckties, which usually suit well only tall and lean males [19].

The style of a bridegroom determines the style of a headgear. To determine the most typical bridegroom's main suit for the Ukrainian wedding, a "screen" survey was conducted, in which 107 people participated. 43,9\% chose the option without a headgear (Figure 6, b, 26,2\% chose a Cossack hat from an artificial astrakhan (Figure 6, a).

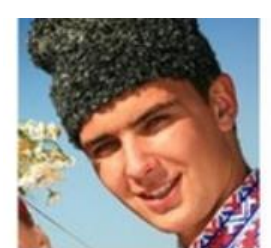

a

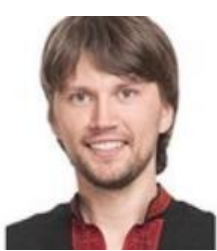

b

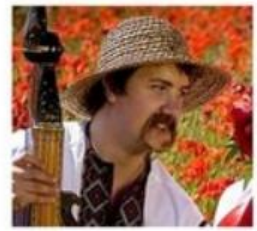

C

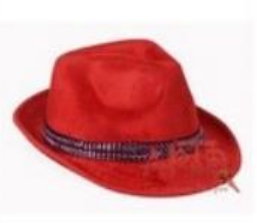

d

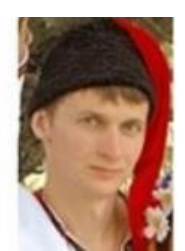

e

Figure 6. Current hats for a groom

Proceedings of IITIIE2018 ISSN 1314-9474 


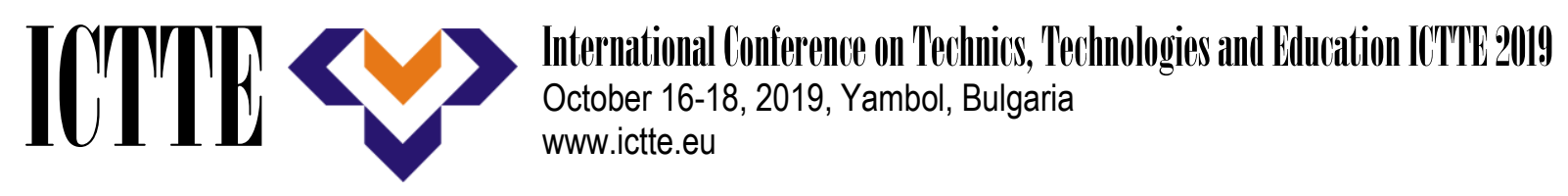

To determine the most characteristic boutonniere of the bride [8] for the Ukrainian wedding, a "screen" survey was conducted, in which 164 people took part. Most of the votes $(38,4 \%)$ were given to a boutonniere with a composition of white roses and a red ribbon (Figure 7, b).

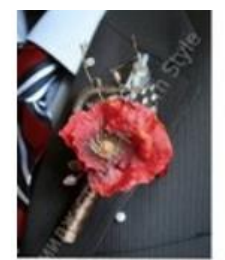

a

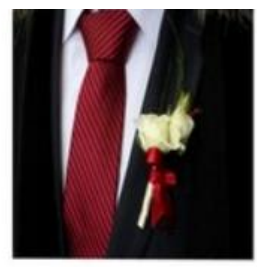

b

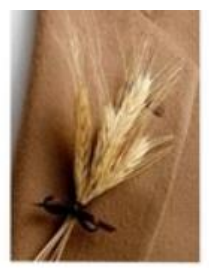

C

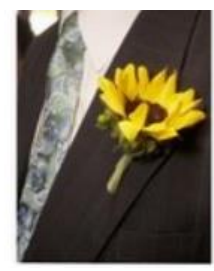

d

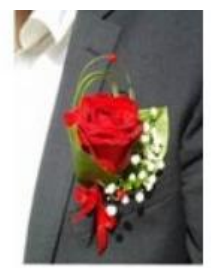

e

Figure 7. The actual boutonnieres of a groom

The traditional wedding capsule of the bride's main dress includes a dress, a headgear, a bouquet and shoes. For the wedding ceremony in the Ukrainian style, the following ensembles of the bride's clothing are the most common: a short white dress with ethnic embroidery (Figure 8, a); a long white dress with embroidery beads (Figure 8, b); a traditional embroidered shirt and a skirt [15] (Figure 8, c), a designer dress with an ethnic embroidery (Figure 8, g) and a traditional dress with artificial flowers (Figure 8, g). To determine the most popular basic product, a "screen" survey was conducted, in which 140 respondents took part. The largest number of votes (38.6\%) was given to a designer dress with ethnic embroidery (Figure 8, g).

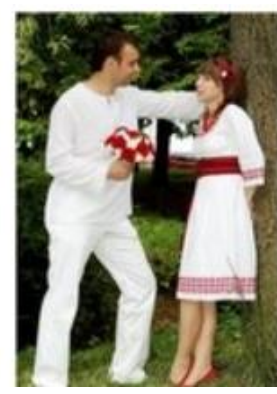

a

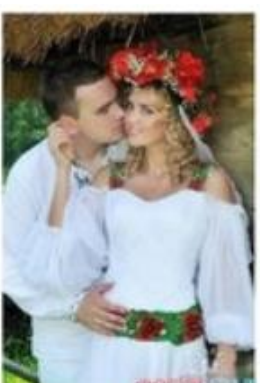

b

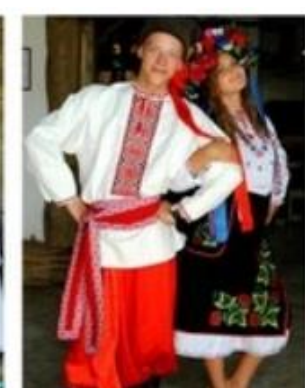

C

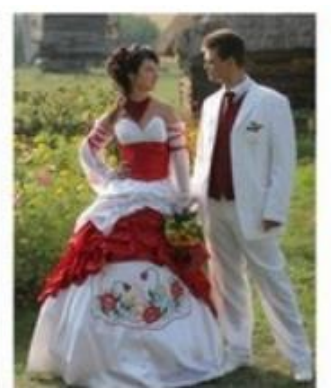

d

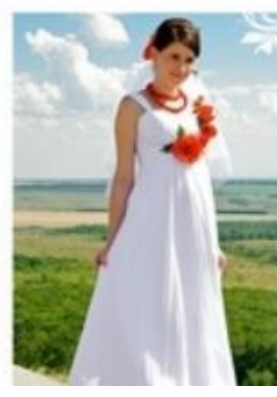

e

Figure 8. Top bride ensembles in the Ukrainian style

Bride's Bouquet is not less important attribute of a wedding than a wedding dress. The bouquet is usually assembled exclusively from natural flowers [25]. To determine the most typical bouquet of the bride at the wedding ceremonies in the Ukrainian style, a "screen" survey was conducted, in which 140 respondents took part. The most votes 34,3\% were given to a bouquet of red and white roses in the form of a drop (Figure 9, a).

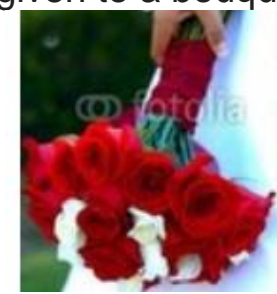

a

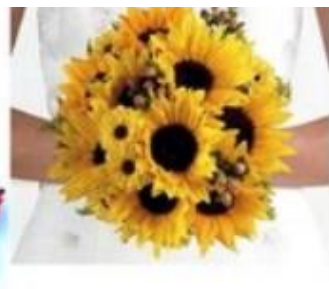

b

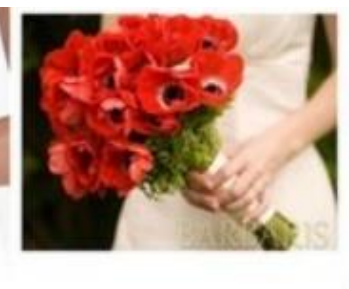

C

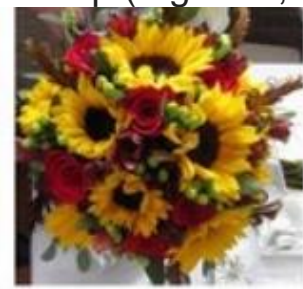

d

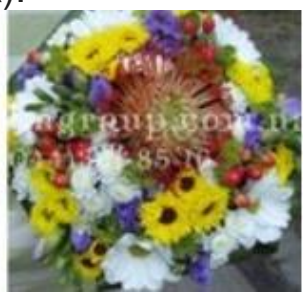

e

Figure 9. Top wedding bouquets in the Ukrainian style Proceedings of IITTIE2018 ISSN 1314-9474 


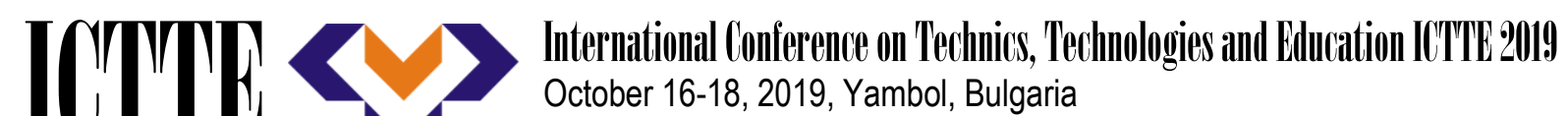 www.ictte.eu}

Today, some brides do not pay less attention to shoes than to wedding dresses. Most often they use the following models of shoes: ballet shoes, bootlings, boots, sandals, shoes [3].

To determine the most typical bride's shoes for the Ukrainian wedding, a "screen" survey was conducted, in which 149 respondents participated. $43,6 \%$ of the respondents chose red shoes with black embroidery (Figure 10, a).

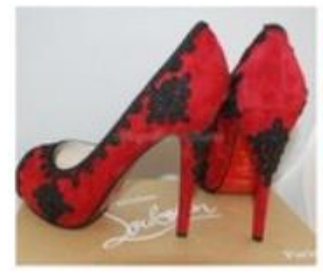

a

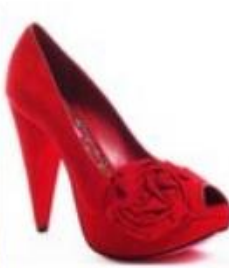

b

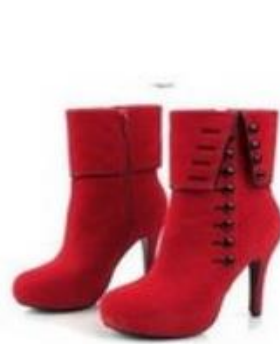

C

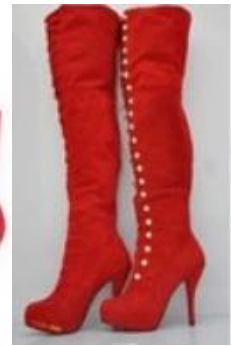

d

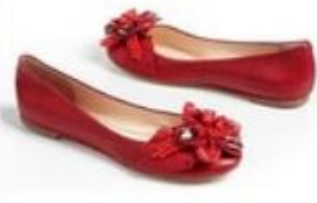

e

Figure 10. Trendy shoes for the bride in the Ukrainian style

The classic headgear of the bride is a veil, which symbolizes the transition of a girl from parents' care to her husband's power. Today, the traditions of the past years have gone to the background, and the brides are free to choose not only the length and color of the veil, but also its presence in general in the wedding dress. Of course, a veil adds a gay image of femininity and gives the entire ensemble a special color.

Also, brides are often found in hats. If the bride wants to become a real princess, she chooses a diadem. A wedding diadem, being part of a hairstyle, dramatically attracts the attention of others.

The headgear of the traditional Ukrainian bride is a wreath [25]. Wreaths can be of the most varied colors, they can also consist of artificial or natural flowers.

To determine the most typical bride's headgear for the Ukrainian wedding, a "screen" was conducted - a survey of 144 people. $43.8 \%$ of respondents chose a combination of white veil and a traditional Ukrainian wreath made of artificial flowers (Figure 11, a).

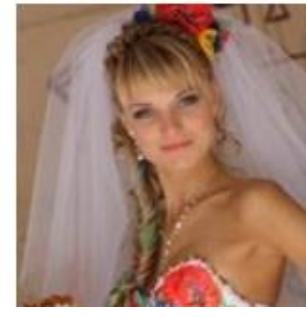

a

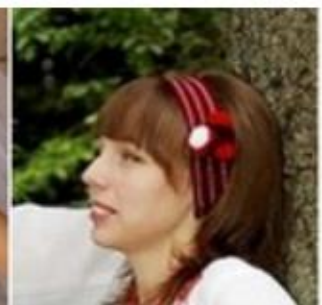

b

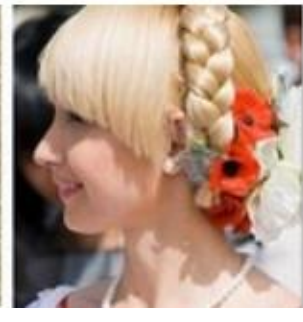

C

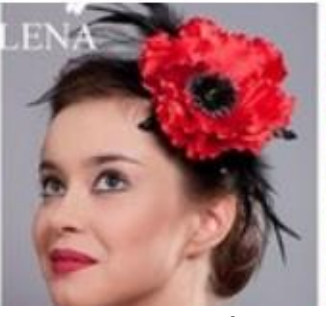

d

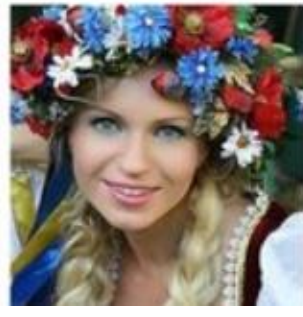

e

Figure 11. Current bride's headgear

To determine the most typical decorations of the bride [1] for the Ukrainian wedding, a "screen" survey was conducted, in which 127 people took part. 39,4\% respondents chose a necklace made of small black beads and red roses (Figure 12, c). 32,3\% of the respondents chose handmade cuff decoration of wool in the form of grizzly berries and its leaves (Figure $12, b)$. 


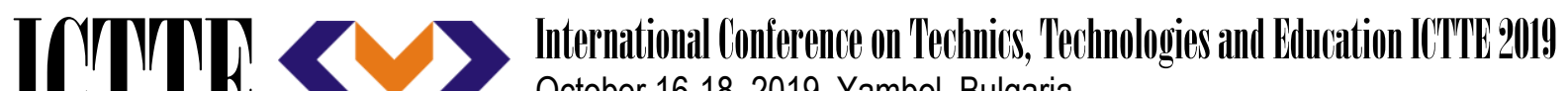 October 16-18, 2019, Yambol, Bulgaria www.ictte.eu}

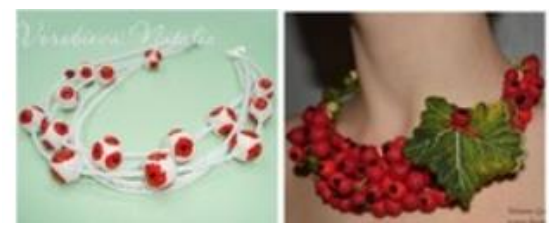

a

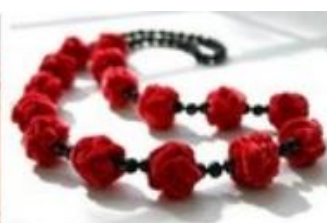

C

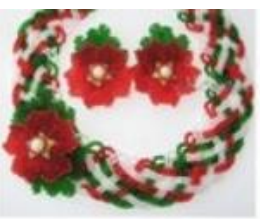

d

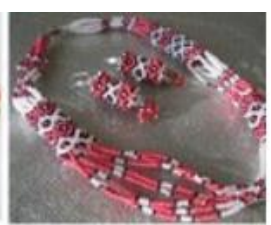

e

Figure 12. Actual decorations used by a bride

\section{RESULTS}

Recommendations $[4,10,12,16,22,23]$ have been given to form the optimum wedding capsule in the Ukrainian traditions. The capsule of the traditional ethnic Ukrainian wedding dress was as follows: the bride's capsule included a bridal shirt, a sleeveless jacket (captop), plakhta, an apron (stock), an upper suit, a skirt, a belt; the bridegroom's capsule consisted of a wedding shirt, pants, a belt, a sleeveless jacket, a Ukrainian overcoat, a vest, a wedding rushnik (wedding towel), a headscarf.

The optimal capsule of the contemporary bridegroom's wedding dress includes an embroidered short-sleeved shirt, a Ukrainian belt and classic trousers or a classic suit, a shirt and shoes in the color of the chosen theme (Figure 13, a).

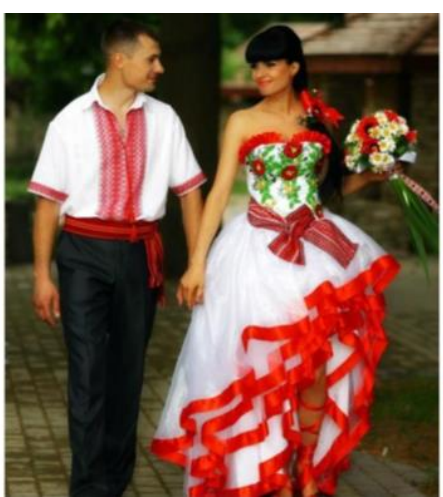

a

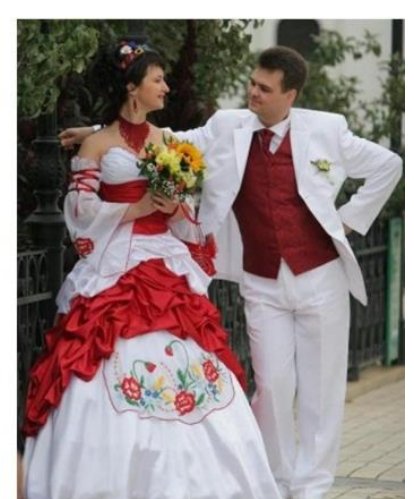

b

Figure 13. Optimal capsule of a wedding outfit for a bridegroom

The optimum imagery of the additions to the bridegroom's dress is made up of an embroidered Ukrainian-style tie, an artificial astrakhan Cossack hat (or without a headgear), and a boutonniere with a composition of white roses and a red ribbon (Figure 14).
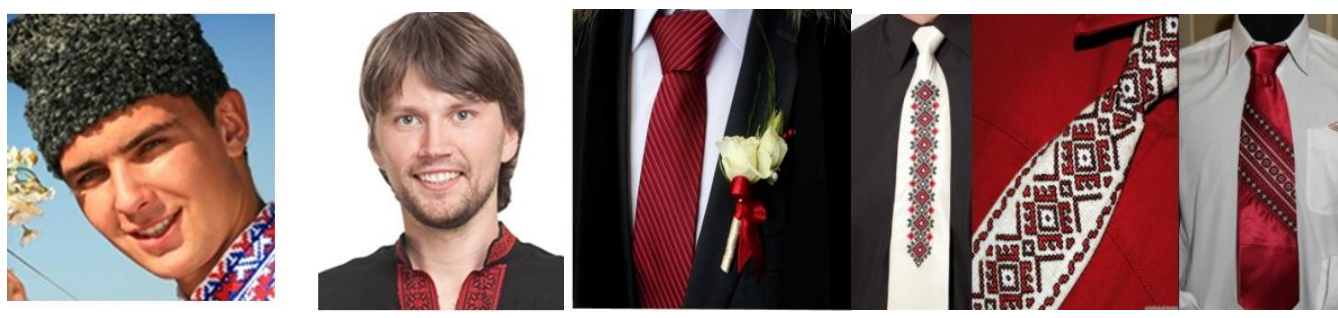

Figure 14. Optimal imagery of additions to the bridegroom's outfit

Proceedings of IITTIL2018 ISSN 1314-9474 


\section{IITTR 2 ( www.ictte.eu}

The wedding clothing items capsule for a bride has the following characteristics: a white designer dress with ethnic embroidery, red shoes with black embroidery and a bouquet of red and white roses in the form of a drop (Figure 15).
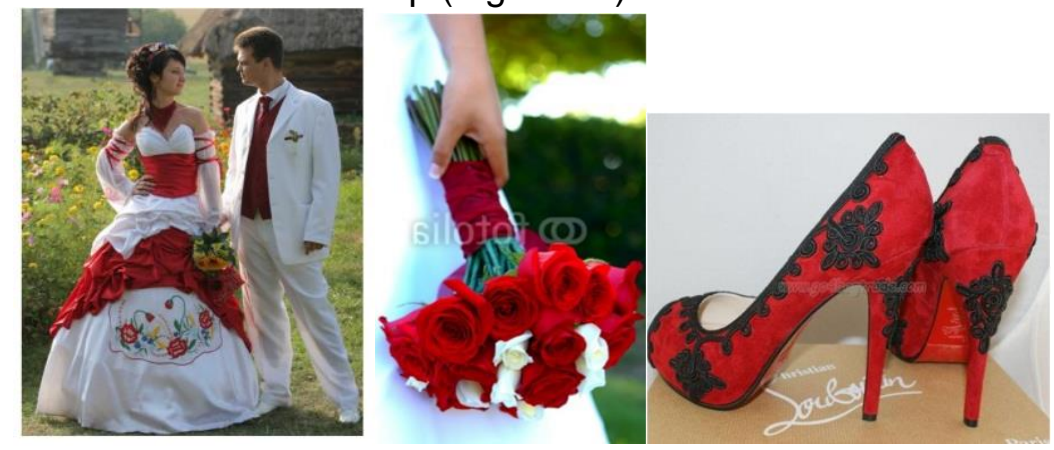

Figure 15. Optimal capsule of a bride's wedding wear

The optimal imagery of the additions to the bride's dress includes a veil and a traditional crochet of flowers, a red clutch decorated with flowers, a necklace made of black beads and red roses (Figure 16).
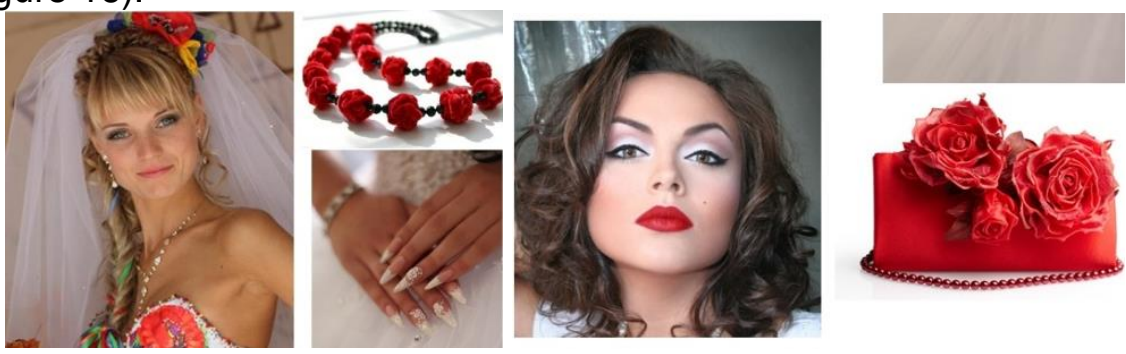

Figure 16. Optimal imagery of additions to the bride's dress

Compositional transformation of a bride's wedding dress is developed taking into account the principles of emotional engineering $[2,6,14,17]$. The oval character of the wedding dress is written only by the smooth curve forming the oval. Also, oval lines depict the smaller elements of the whole silhouette - sleeves, skirts - along with the main line, express the unity of the character of the outfit. It is dynamic and at the same time calm and monumental in all three researched ensembles (Figure 17).

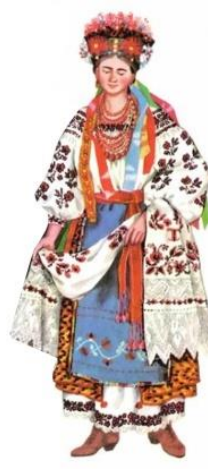

a

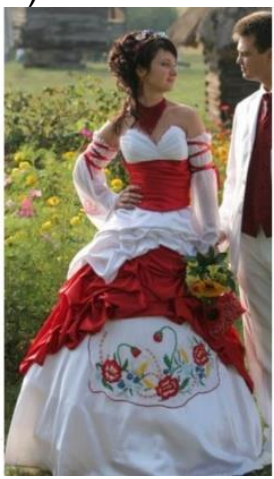

b

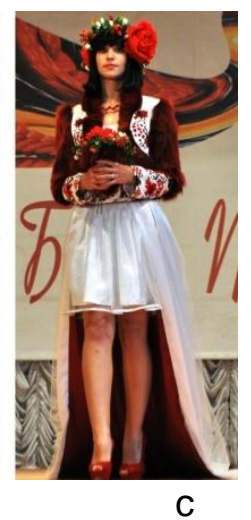

Figure 17. Compositional transformation of a bride's wedding wear

Proceedings of IITTIE2018 ISSN 1314-9474 


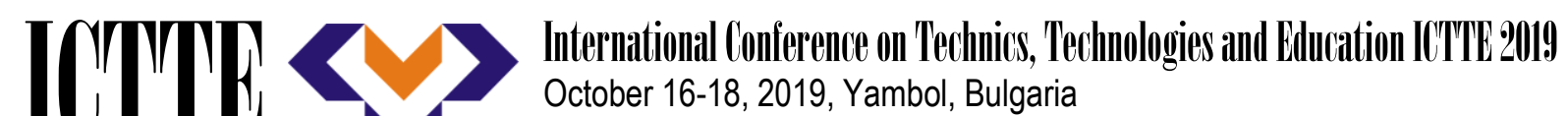 \\ www.ictte.eu}

The oval form is convenient for the manifestation of unity, because its lines are calm, voluminous and do not constrain human movements. Unity of character as a compositional means, in addition to the organizing role, plays an important role in achieving the emotional expressiveness of the presented wedding ensembles (Figure 17).

The character of the oval form of the investigated wedding ensembles is simplified, as shown in Figure 18. There is a unity in the nature of the shape of the presented models due to the simplified notation.

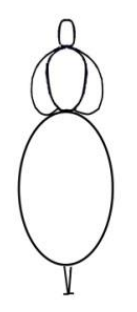

a

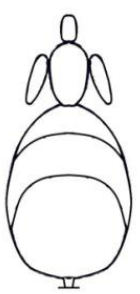

b

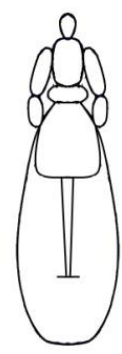

C

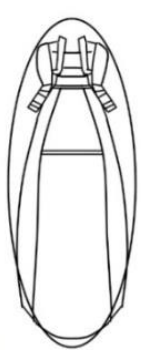

d

Figure 18. Brief notation of the shape of the bride's wedding dress

For the Ukrainian traditional wedding ensemble (Figure 18, a), the short notation is represented by 4 ovals, namely: a brassiere, sleeves and a skirt.

The short entry of the dominant dress in the survey consists of 8 ovals $(18, b)$ : the bodice, sleeves, the 1st, 2nd and 3rd layers of the skirt. The entry was developed with use of the specific software "OOO Draw" (add-on "GEKKR") [21].

The notation of a designer wedding dress in the Ukrainian style $(18, c)$ consists of 8 ovals: a belt, a bodice, an upper and lower part of sleeves, a skirt and a loop. A brief notation of the rhythmic structure of the ensemble is presented in Figure 18. The curvature of the oval is transferred to the shoulder line, the shape of the sleeves, the loop and the constructive lines. As it can be seen from Figure 19, the Ukrainian traditional wedding ensemble $(19$, a) and the designer wedding dress in the Ukrainian style $(19, b)$ are characterized by the focus on the shoulder line and headgear. There is a certain "triangular dominant" [20], which is based on the main part of the embroidery and the brightness of the image. The vertex of the triangle has the symbolism of the female element - fertility. In these ensembles, the crown of flowers on the head serves as the triangle vertex.

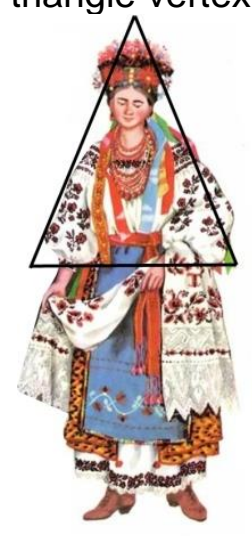

a

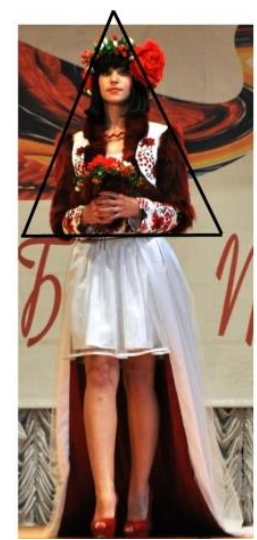

b

Figure 19. Compositional dominant Proceedings of IITTIE2018 ISSN 1314-9474 


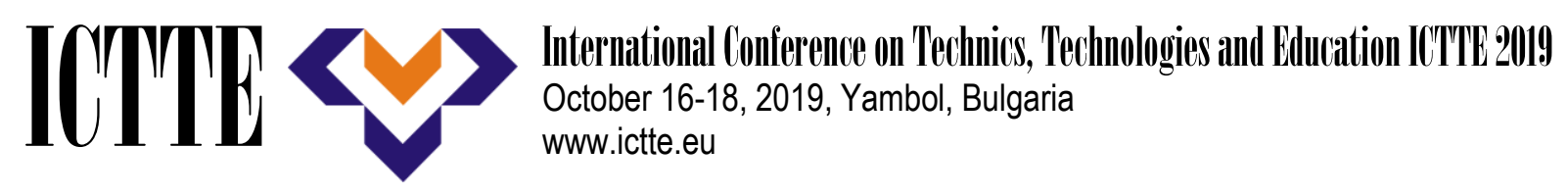

\section{CONCLUSIONS}

The compositional dominant of the wedding Ukrainian bride's dressing capsule is based on a combination of ovals of the bodice form, sleeves and skirts with a triangular dominant of the compositional accent on the shoulder belt and a headgear with the base of the triangle on the line of embroidery limitation. The formula for notation the character of the oval form of wedding bride's dress is based on the proportional division of the ethnic wedding dress.

\section{REFERENCES}

[1] Belolutskaya K. (2017). Jewelry for the bride 2018: trends and tendencies. [Online]. Available: https://www.zankyou.ru/p/ukrasheniya-nevesty-2018-tendencii-i-trendy [201712-20].

[2] Chulovskaya N. (2017). What is a capsular wardrobe and how to collect it? [Online]. Available: https://www.the-village.com.ua/village/service-shopping/style-things/264457scho-take-kapsulniy-garderob [2017-11-07].

[3] Derhousova S. (2012). How to choose a wedding shoes. [Online]. Available: http://odnako.su/women/relationship/marriage/-252517-kak-vybrat-svadebnuyu-obuv/ [2012-07-07].

[4] Dong A., Shan D., Ruan Z., Zhou L., Zuo F. (2013). The design and implementation of an intelligent apparel recommend expert system. Mathematical Problems in Engineering, Vol. 2013, (2013), pp. 1-8. Article ID 343171, http://dx.doi.org/10.1155/2013/343171.

[5] Embroidery is a multi-faceted phenomenon of Ukrainian culture. [Online]. Available: http://www.refsua.com/referat-5044-5.html.

[6] Gong D., Yuan J., Sun X. (2011). Interactive genetic algorithms with individual's fuzzy fitness. Computers in Human Behavior, No. 27, (2011), pp. 1482-1492.

[7] Gorina G. (1981). Modeling the form of clothing. Light and food industry, Moscow, (1981).

[8] How to choose a boutonniere for the groom. (2019). [Online]. Available: http://wedding.ua/flowers/7521.

[9] Petrov A. (2015). How to choose a Men's wedding shirt ? [Online]. Available: https://wek.ru/kak-vybrat-muzhskuyu-rubashku-dlya-svadby [2015-06-04].

[10] Kardash O., Lugantseva D. (2013). Style features of national in Ukrainian design. Theory and Practice of Design, Issue 6, (2013), pp. 74-81.

[11] Kosmina T., Vasina Z. (1989). Ukrainian wedding dress. Ethnographic Reconstructions. (title-wrap + 16 cards with brief history on the back). Art, Kyiv, (1989).

[12] Kostelna M. (2016). Ethno-motives in the works of Ukrainian fashion designers at the beginning of the 21st century: innovations and traditions. Visnyk of KSADA, No.1, (2016), pp. 16-19.

[13] Kuleshova S. (2017). Applications of Kansei Engineering in clothing design. Actual problems of modern science. Monograph: ed. by Musial J., Polishchuk O., Sorokatji R. Bydgoszcz, Poland, (2017), pp. 258-266.

[14] Lu H. Chen Y., Du J. (2013). An interactive system based on Kansei Engineering to support clothing design process. Research Journal of Applied Sciences, Engineering and Technology, No 6 (24), (2013), pp. 4531-4535.

[15] Medvedchuk G. (1993). Beauty of Podillya folk embroidery. Publishing House "Podillya", Khmelnytskyi, (1993).

[16] Melnyk M.T. (2018). Features of the use of elements of the traditional Ukrainian costume when creating fashion-collections. [Online]. Available: http: // mtmfashion. blogspot.com/ 2012/08 / blog-post_21.html [2018-04-07].

\section{Proceedings of ITTTE2 2018 ISSN 1314-9474}




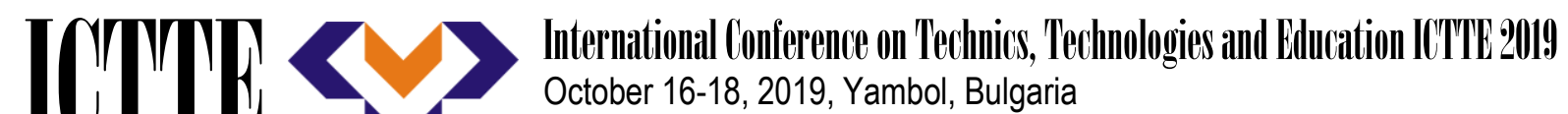 \\ www.ictte.eu}

[17] Nada Y., Meshref H. (2014). Analysis, design, and implementation of intelligent expert system for clothes style selection. International Journal of Computer Applications (0975 8887). Vol. 105, Issue 4, (2014), pp. 15-20.

[18] Nikolaeva T. (1996). History of the Ukrainian costume. Lybid, Kyiv, (1996).

[19] Polovinkin S. Tie in a men's suit. [Online]. Available: http://www.galstuknn. ru/bibilioteka/texts/6-galstuk-v-muzhskom-kostyume

[20] Principle of dominant. (2012). [Online]. Available: http://vita-studia.com/?p=1193 [201211-05].

[21] Slavinska A.L. The development of the method of automated designing of models of women's suits with the use of the software module "GEKKR" / A.L. Slavinska, I.O Zasornova, O.S. Zasornov // Bulletin of the Kyiv National University of Technology and Design. - №6. - 2011. - p. 52-58.

[22] Susak K., Stefiuk N. (2006). Ukrainian folk embroidery. Naukovyi svit, Kyiv, (2006).

[23] Syrotenko O., Yatsyuk N. (2016). Method of selection of rational parameters of national embroidery taking into account the part of decoration of a part. Bulletin of the Khmelnytskyi National University, No. 6, (2016), pp. 93-98.

[24] Ukrainian wedding traditions. (2017). [Online]. Available: https://destinations.com.ua /travel/authentic-ukraine/192-ukrainian-wedding-traditions [2017-02-21].

[25] Voitovich V. (2005). Myths and legends of ancient Ukraine. Educational book. Bogdan, Ternopil, (2005).

[26] Voropai O. (1991). The customs of our people. Ethnographic essay: In 2 t. Oberig, Kyiv, (1991). 